\title{
Mandenkan
}

MANDENIKAN Bulletin semestriel d'études linguistiques mandé

57 | 2017

Numéro 57

\section{The morphosyntax of adjectives in Seenku [sos]}

La morphosyntaxe des adjectifs en seenku

МОРФОСИНТАКСИС ПРИЛАГАТЕЛЬНЫХ В СЕЕНКУ

\section{Laura McPherson}

\section{(2) OpenEdition}

Journals

Electronic version

URL: https://journals.openedition.org/mandenkan/1041

DOI: 10.4000/mandenkan.1041

ISSN: 2104-371X

\section{Publisher}

Llacan UMR 8135 CNRS/Inalco

\section{Electronic reference}

Laura McPherson, "The morphosyntax of adjectives in Seenku [sos]", Mandenkan [Online], 57 | 2017, Online since 14 December 2017, connection on 08 July 2021. URL: http://journals.openedition.org/ mandenkan/1041; DOI: https://doi.org/10.4000/mandenkan.1041

This text was automatically generated on 8 July 2021.

\section{cc) (†) (2)}

Les contenus de Mandenkan sont mis à disposition selon les termes de la Licence Creative Commons Attribution - Pas d'Utilisation Commerciale - Partage dans les Mêmes Conditions 4.0 International. 


\title{
The morphosyntax of adjectives in Seenku [sos]
}

\author{
La morphosyntaxe des adjectifs en seenku \\ МОРФОСИНТАКСИС ПРИЛАГАТЕЛЬНЫХ В СЕЕНКУ
}

Laura McPherson

\section{Introduction}

1 This paper describes the morphosyntax of adjectives in Seenku as both modifiers and predicates. Though only a small class of lexical items can be identified as purely adjectival (as opposed to verbal or nominal), the lexical class reveals a number of interesting morphosyntactic phenomena. First, Seenku adjectives follow similar patterns of plurality as those found in Dan (Vydrine 2004, 2007), with reduplication and plural suffixation on the adjective and variable plural suffixation on the noun. Second, adjectival predicates involve an unexpected reflexive pronoun between the copular verb and the following adjective, only attested elsewhere in a small number of South Mande languages. I suggest that the usage of this pronoun derives from the fact that adjectival predication is predication of an NP, and adjectives cannot form their own NPs. They require a pronominal head to prop them up, and co-indexation with the subject results in a reflexive pronoun.

2 In the following, I first provide background on Seenku and its phonology (\$2), before discussing the category of adjectives in the language ( $\$ 3)$. I then describe adjectives used as modifiers ( $\$ 4$ ), including their plural marking, and as predicates ( $\$ 5$ ). Finally, I compare the Seenku predicate construction to other Mande predicate constructions and discuss the historical origins of the reflexive pronoun before concluding ( $\$ 6)$. 


\section{Language background}

3 Seenku, also known by its exonym Sembla/Sambla, is a member of the Samogo group of Northwestern Mande and is spoken by 16,000 people in southwestern Burkina Faso. It has two primary dialects, southern Seenku (Gbeneku) spoken by 11,000 people and northern Seenku (Timiku) spoken by 5,000 people and described by Prost (1971). This paper draws on primary data on the southern dialect gathered by the author between 2012 and 2016 in Bouendé (Gbene), Vienna, and New York City.

Before turning to the main topic of the paper, adjectives, I briefly lay out the morphophonological structure of the language. Seenku has undergone extensive reduction, leaving the vocabulary largely mono- and sesquisyllabic, a term generally reserved for Southeast Asian languages (Matisoff 1990, Brunelle and Pittayaporn 2012, Butler 2014). In other words, where many other Mande languages see reduction or deletion of certain vowels in certain stress positions (e.g. initial unstressed high vowels in an iambic foot, Bambara, Green 2010), these reduction patterns in Seenku have resulted in restructuring and concurrent loss of the stress system, with the original full vowels ostensibly no longer part of the underlying representation. As seen in (1a), monosyllabic words can have either a short or long vowel, with or without a coda nasal. In the sesquisyllabic examples in (1b), a cognate disyllabic form or reconstruction is placed in parentheses for comparison: ${ }^{1}$

(1a) Monosyllabic vocabulary

\begin{tabular}{|l|l|}
\hline$b \hat{\imath}$ & 'goat' \\
\hline$t u ̈ ~$ & 'thatch' \\
\hline kyènn & 'peanut' \\
\hline$b a \hat{a} a$ & 'balafon' \\
\hline
\end{tabular}

(1b) Sesquisyllabic vocabulary

\begin{tabular}{|c|c|c|}
\hline $\operatorname{təg} \hat{\varepsilon}$ & 'chicken' & (cf. Proto-Mande *tJqE, Vydrine 2016) \\
\hline bəlě & 'big' & (cf. bèlebéle Bamabara, Vydrine 2009) \\
\hline fənว̈ [frȭ] & 'monkey' & (cf. fJnon, Dzùùngoo, Traoré and Traoré 1998) \\
\hline
\end{tabular}

7 When pronouncing sesquisyllabic words slowly, most consultants do not reconstruct a vowel in the initial half syllable. ${ }^{2}$ It is either pronounced as a schwa or quickly skipped over to pronounce the following full syllable, suggesting perhaps an underlying representation with a consonant cluster (e.g. $/ \operatorname{tg} \hat{\varepsilon} /$ ) with an excrescent schwa (Butler 2014). If the second consonant is a liquid, the schwa is often omitted, e.g. [bəlě] [blě] 'big'.

8 Seenku has seven oral vowel qualities and five nasal vowel qualities: 

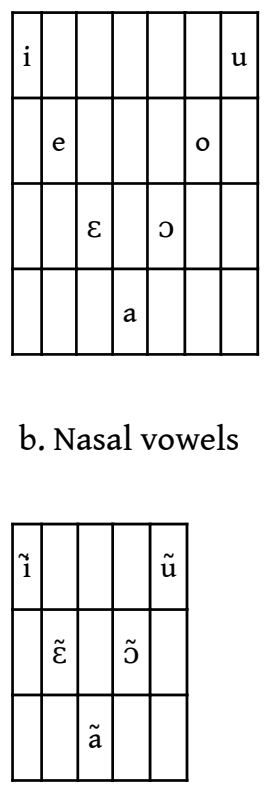

Length is contrastive for all vowels.

12 In addition, Seenku uses the following diphthongs:

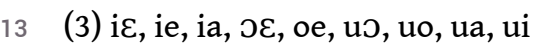

14 As we can see, diphthongs cannot combine [+ATR] and [-ATR] vowels. ${ }^{3}$ Interestingly, the diphthong-initial vocalic element (any of /i, $\mathrm{u}, \mathrm{o}, \mathrm{J} /$ ) is non-moraic, acting as a glide

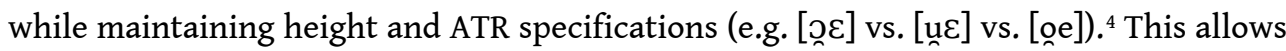
length to be contrastive for diphthongs as well (e.g. "i boe 'their backs' vs. boee 'mats') without creating trimoraic nuclei. The ATR contrast can also be seen in the following pairs of words, both monomorphemic (4a) and bimorphemic (4b).

(4a) kôo 'be born' kôj 'walk'

16 kyërè 'sleep' kyËrž 'call's

17 (4b) ko-ëe 'sing' (antipassive) fJ- $\varepsilon \varepsilon \varepsilon$ 'uproot' (antipassive)

18 Given the paucity of segmental affixation in Seenku, there are not many opportunities to investigate synchronic ATR alternations. Seenku has a rich tonal system, with four level tones, captured by the following system of tone features (Pulleyblank 1986, McPherson 2017):

(5) Tone features in Seenku

\begin{tabular}{|l|l|l|l|l|}
\hline & X (extra low) & L (low) & H (high) & S (super high) \\
\hline [upper] & - & - & + & + \\
\hline [raised] & - & + & - & + \\
\hline
\end{tabular}


The table in (6) illustrates the four level tones in Seenku vocabulary; note that all underlying H-toned singular nouns are realized as an $\mathrm{H}-\mathrm{X}$ contour, argued in McPherson (2017) to be a repair for a tonotactic restriction against final $\mathrm{H}$ :

(6)

\begin{tabular}{|c|c|c|c|c|}
\hline & $\underline{X}$ & $\underline{\mathrm{L}}$ & $\underline{\mathrm{H}}$ & $\underline{s}$ \\
\hline \multirow[t]{2}{*}{ Pronoun } & 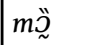 & & mó & $m^{\prime \prime} i$ \\
\hline & 3SG.GEN & & 1SG.EMPH & 1PL \\
\hline \multirow[t]{2}{*}{ Verb } & $b a ̈$ & & sóo & $b_{a}^{\prime \prime}$ \\
\hline & do & & sell & hit \\
\hline \multirow[t]{2}{*}{ Sg. Noun } & $b \varepsilon ̋ \varepsilon$ & & $b \hat{\imath}$ & sú \\
\hline & pig & & goat & antelope \\
\hline \multirow[t]{2}{*}{ Pl. Noun } & & $b \dot{\varepsilon} \varepsilon$ & & $b_{i}^{\prime}$ \\
\hline & & pigs & & goats \\
\hline \multirow[t]{2}{*}{ Numeral } & suč & nò & soén & tó \\
\hline & three & five & one & ten \\
\hline \multirow[t]{2}{*}{ Adverb } & 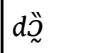 & kòrò & dóoní & $k \notin \tilde{\sim} \varepsilon$ \\
\hline & today & yesterday & a little & tomorrow \\
\hline
\end{tabular}

22 As the table in (6) shows, the four level tones are not equally represented in all morphosyntactic categories. $\mathrm{L}$ is the most restricted tone in the language, never appearing in the underlying forms of open class vocabulary like nouns and verbs. It is derived by plural formation in nouns, arguably due to a [+raised] tone feature marking the nominal plural; for more on plural formation, see $\$ 4.2$ below. It would be tempting to view Seenku as a three-tone language, with tonal modification deriving the fourth level, but numerals and adverbs show evidence of all four tones in underlying forms.

These four level tones can combine to form numerous contour tones. The most common of these is $\mathrm{H}-\mathrm{X}(\hat{\mathrm{a}})$, shown in the table above, which takes the place of underlying $\mathrm{H}$ for singular nouns and certain intransitive verb constructions. X-H (aá) must also be an underlying contour tone, for we find on the surface a number of X-H-X (äâ) tri-tone contours on singular nouns, e.g. dâa 'hanging basket holder'. Other attested contour tones include L-S (ă), S-X (ä), X-S (ää), X-S-X (ää), H-S (áä), S-H (äá), XL (äà), and H-L (áà), though many of these are derived either through tonal morphology or vowel hiatus resolution and are only found on long vowels. As we will see below, L-S is a common melody for adjectival stems. 


\section{3. "Adjective" as a syntactic category}

It is a widely recognized fact that African languages tend to have very small, and often closed, classes of true adjectives (Welmers 1973, Houis 1977, Dixon 1982, Segerer 2008). Seenku is no exception. In my current data, I count up to thirteen stems that behave morphosyntactically as adjectives, compared to many more attributive meanings encoded in verbal stems and some ideophonic forms.

There is no single set of crosslinguistic criteria to distinguish adjectives from other syntactic categories (usually nouns and verbs). Evidence is often drawn from morphophonological or morphosyntactic differences, including word order, agreement, tone patterns, or predicate structures (see e.g. Creissels 2005). For Seenku, two criteria are used to distinguish adjectives from deverbal modifiers: 1. Deverbal modifiers have a corresponding verb stem, which undergoes regular verbal inflection processes, while adjectives do not. 2. As predicates, deverbal modifiers typically precede the copular verb, while adjectives follow. As we will see below, this difference in word order correlates with the presence of a reflexive pronoun: adjectival predicates are obligatorily preceded by a reflexive pronoun, which is absent with deverbal modifiers.

To illustrate this distinction between adjectives and deverbal modifiers, let us first consider the attributive forms in (7), consisting of a noun and a following modifier:

(7a) jəbé tiè 'black clothes'

(7b) jəb"e gว̌J 'dry clothes'

In each case, the modifier carries L-S tone and follows the noun. However, based on Criterion 1, we can distinguish 'black' from 'dry' by the fact that 'black' has no corresponding verb (8a) while 'dry' does ( $8 \mathrm{~b})$, suggesting that 'dry' as a modifier is a participial form derived from the verb while 'black' is inherently an adjective:

\begin{tabular}{|c|c|c|c|c|c|c|c|c|c|}
\hline (8a) & мәпї & $s i$ & jəbe & $b \grave{a}$ & $n \varepsilon$ & $\ddot{a}$ & təgö & $i$ & tiè. \\
\hline & woman & be & clothes & make.REAL & in & $3 \mathrm{sg}$ & become.IRREAL & REFL & black \\
\hline
\end{tabular}

'The woman is blackening the clothes.'

\begin{tabular}{|c|c|c|c|c|c|}
\hline (8b) & Mó & ${ }^{\prime}{ }_{S}^{\prime \prime} i$ & gôว & gว̀ว & $n{ }^{\prime \prime}$. \\
\hline & 1SG.EMPH & be & wood & dry.REAL & in \\
\hline
\end{tabular}

\section{'I am drying wood.'}

In (8a), there is no verb for 'blacken', so a periphrastic causative construction must be used instead, translating to 'making the clothes become black'. In (8b), by contrast, the stem gว̌J is used as a verb with no change in form (the $S$ tone is realized on the postposition $n \varepsilon$ ). It is found in the same progressive construction as any regular active verb. In fact, there are no morphosyntactic differences between what could be described semantically as "qualitative verbs" and other verbs in Seenku. 

adjectives follow the copular verb and take a reflexive pronoun (9a). Deverbal modifiers precede the copular verb (9b); for comparison, (9c) shows that this is the same construction used with stative verbs.

\begin{tabular}{|l|l|l|l|l|}
\hline (9a) & Jəğ̈ & š̃ & í & tiě. \\
\hline & dog & be & REFL & black \\
\hline
\end{tabular}

'The dog is black.'

\begin{tabular}{|c|c|c|c|}
\hline (9b) & GôJ & gว̌J & ${ }^{\prime}{ }^{\prime \prime s i . ~}$ \\
\hline & wood & dry.РТСР & be \\
\hline
\end{tabular}

'The wood is dry.'

\begin{tabular}{|c|c|c|c|}
\hline (9c) & Mó & təğі & ${ }^{\prime}{ }_{\text {s.i. }}^{\prime \prime}$. \\
\hline & 1SG.EMPH & stand.РТСP & be \\
\hline
\end{tabular}

'I am standing.'

37

word order *jəgë tiè 'śsi was rejected as ungrammatical, prompting laughter from the consultants. For the majority of deverbal modifiers, placing the modifier after the copular verb is likewise judged ungrammatical, though gǒo 'dry' is a rare case that straddles the boundary between adjective and deverbal modifier and can come in either position.

We can also identify several criteria distinguishing adjectives from nouns: 1 . Adjectives undergo a reduplicative plural formation process, while nouns do not. 2. Nouns may stand alone or head a phrase, while adjectives cannot. 3. Adjectives and nouns employ different coordination strategies. 4. The order of head and modifier differs between Noun Adjective and Noun Noun constructions.

The first criterion states that plural formation differs between the two categories: though both categories may undergo featural suffixation for plural (see \$4.2), adjectives also obligatorily show initial reduplication (10a), which is ungrammatical on nouns (10b):

(10a) jŭ ‘long' jú-jǔ̀ ‘ ‘long (pl.)’

(10b) jü 'hill' jui ‘hills' (*jú-juì)

The vocalic and tonal changes seen on the stem can affect both nouns and adjectives, but the reduplication pattern is confined to adjectives.

The second criterion distinguishing nouns and adjectives is that nouns are able to stand alone and head a noun phrase, while adjectives are not. I contrast this behavior here with a noun phrase acting as a direct object of a transitive verb: 


\begin{tabular}{|c|c|c|c|c|c|}
\hline (11a) & $M i$ & ${ }^{\prime}{ }_{\text {śt }}^{\prime \prime i}$ & {$[b \varepsilon ̈ \varepsilon]_{N P}$} & $s \grave{a ̀ ~}$ & $n \varepsilon$ \\
\hline & 1PL & be & pig & buy.REAL & in \\
\hline
\end{tabular}

'We are buying a pig.'

\begin{tabular}{|c|c|c|c|c|c|c|}
\hline (11b) & $M i ̂$ & ${ }^{\mathrm{I}} \mathrm{s} / \mathrm{i}$ & {$[b \ddot{\varepsilon} \varepsilon$} & $t i \check{e}]_{N P}$ & $s \grave{a}$ & nहै. \\
\hline & 1PL & be & pig & black & buy.REAL & in \\
\hline
\end{tabular}

'We are buying a black pig.'

\begin{tabular}{|c|c|c|c|c|c|c|}
\hline (11c) & $M i$ & ${ }^{\prime}{ }_{S i}^{\prime \prime i}$ & {$[\ddot{a}$} & $t i \check{e}]_{N P}$ & $s \grave{\sim}$ & nع. \\
\hline & 1PL & be & $3 S G$ & black & buy.REAL & \\
\hline
\end{tabular}

'We are buying a black one.'

A noun phrase can consist of a single noun, as in (11a); noun phrases can also involve a head noun followed by modifiers, as in (11b). However, a noun phrase cannot consist of an adjective alone $\left(*[\text { tiě }]_{\mathrm{NP}}\right)$. In (11c), we see that 'black' must be supported by a pronoun, here the general 3SG ă; the phrase would be ungrammatical with tiě on its own. For further discussion of this pronominal structure, see \$5. Of course, this evidence on its own does not confirm a distinction in syntactic category, since inalienable nouns must also obligatorily appear with a possessor (the default for which is the $3 \mathrm{sG}$ ). Taken together with other evidence, however, it supports a differential treatment of nouns and adjectives in the language.

The third criterion shows us that while both nouns and adjectives can be coordinated, each uses a different coordination strategy:

\begin{tabular}{|l|l|l|l|}
\hline$(12 \mathrm{a})$ & $b \bar{\varepsilon} \varepsilon$ & $t i \check{e}$ & $n \tilde{\varepsilon}-k \stackrel{\sim}{a}-k \stackrel{\sim}{ }$ \\
\hline & pig & black & CONJ-RED-white \\
\hline
\end{tabular}

'black and white pig'

\begin{tabular}{|l|l|l|l|}
\hline$(12 b)$ & $b \ddot{\varepsilon} \varepsilon$ & $t s \partial ̋ k \varepsilon ́$ & $b \hat{\imath}$ \\
\hline & pig & and & goat \\
\hline
\end{tabular}

'a pig and a goat'

The second adjective is both reduplicated and carries what appears to be a prefix $n \varepsilon^{\prime \prime}$-, which I have never seen with nouns. ${ }^{6}$ The reason I treat this as a prefix on the second 
adjective rather than as a free-standing conjunction is that a) the first adjective can be omitted, leaving its meaning implied (jönmä nč-kăa -kă 'a [black] and white cat'), and b) in predicate constructions, the $n \check{\varepsilon}$ - remains strictly adjacent to the adjective, separating it from the reflexive pronoun; see $\$ 5$ below.

The fourth criterion distinguishes Noun Adjective from Noun Noun constructions using word order: in the majority of cases of compound nouns I have seen thus far in Seenku, the head noun is on the right, meaning the modifier precedes the noun. This is of course the opposite of a Noun Adjective construction, where the modifier follows the noun. An example of each construction is given in (13), with the head noun underlined:

\begin{tabular}{|c|c|c|}
\hline (13a) & 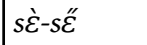 & $\underline{k i}$ \\
\hline & RED-spider & house \\
\hline
\end{tabular}

‘spiderweb' (lit. 'spider house')

\begin{tabular}{|l|l|l|}
\hline$(13 b)$ & $\underline{k} \hat{\imath}$ & móën \\
\hline & house & small \\
\hline
\end{tabular}
it. In (13b), the adjective 'small' modifies the meaning of 'house' but follows it. As the examples above also indicate, there may be tonal interactions between the stems in a Noun Noun compound (here, we see spreading of S), while nouns and adjectives show no tonal interaction.

$$
\text { into Dixon's (1982) types: }
$$

\begin{tabular}{|c|c|c|}
\hline bəlě & 'big' & DIMENSION \\
\hline bő̃ & 'tall' & DIMENSION \\
\hline fว̆o & 'skinny' & DIMENSION \\
\hline$j u \underline{~}$ & 'long' & DIMENSION \\
\hline móën & 'small' & DIMENSION \\
\hline nógว̋ & 'skinny' & DIMENSION \\
\hline
\end{tabular}




\begin{tabular}{|c|c|c|}
\hline jué & 'bad/ugly' & VALUE \\
\hline səgว̌ & 'good/pretty' & VALUE \\
\hline kyərä & 'fresh' & AGE/VALUE \\
\hline səgëe & 'new' & AGE \\
\hline$k a \underline{\sim}$ & 'white' & COLOR \\
\hline$s i \check{\sim}$ & 'red' & COLOR \\
\hline tiě & 'black' & COLOR \\
\hline
\end{tabular}

The semantic types of Seenku's adjectival stems are in line with Dixon's prototypical categories (with the categorical assignment of "fresh" open to interpretation). Morphophonologically speaking, two adjectives have unusual forms. First, nóg’’ 'skinny', is unusual in being disyllabic (rather than sesquisyllabic) with an H-S tone pattern. Second, the adjective móen 'small' is unusual in its H-S-X tone pattern in the singular. As we will see below, it also has an irregular plural form.

The rest of the paper will focus only on the morphosyntax of these true adjectives. I will first address their behavior as nominal modifiers, then turn to their behavior as predicates.

\section{Adjectival modifiers}

61 As is typical for Mande, the noun precedes the modifying adjective. In Seenku, there is no tonal interaction between the two.

\subsection{Singular nouns with adjectives}

I begin by illustrating Noun Adjective sequences with singular nouns. These sequences are a simple concatenation of noun and adjective with no morphophonogical or morphosyntactic adjustments.

(15a) bû kyərä 'fresh grass'

(15b) jöymä tiě 'black cat'

65 (15c) jəgè bəlě 'fat dog'

(15d) kî móën ‘small house'

The only phonological interaction between a noun and an adjective is a regular phonological process by which a floating nasal associated with the noun docks onto the following word, creating a prenasalized stop (or nasalizing sonorants, which do not occur word-initially except in function words). For example:

(16) sầ $\hat{A}^{N}$ bəlě 爁 sâ mbəlě 'big rabbit' 


\subsection{Plural nouns with adjectives}

When a plural noun is modified by an adjective, we find variation in how plurality is marked. In most Mande languages, plural marking (typically a suffix) follows the whole Noun Adjective sequence rather than the noun itself, but in Seenku, this is only partially true. Seenku displays a system of Noun Adjective plurality that most closely resembles South Mande languages like Dan (Vydrine 2004, 2007) in combining reduplication of the adjective, suffixation of the adjective, and suffixation of the noun, though the last is optional.

To frame the discussion of adjectival plurality, I will first summarize the regular nominal plural. As mentioned in §2, Seenku has undergone a lot of reduction, affecting both stem shape as well as morphological exponence. The plural suffixes seen in many Mande languages, including closely related Dzùùngoo (e.g. -rí, marking the definite plural, Solomiac 2014), have become lost in Seenku, leaving behind only tonal and vocalic changes on the base. These changes are consistent with an earlier suffix like -rí, $\mathrm{H}$-toned and with a front vowel, since the two changes we see in the plural are tone raising and vowel fronting:

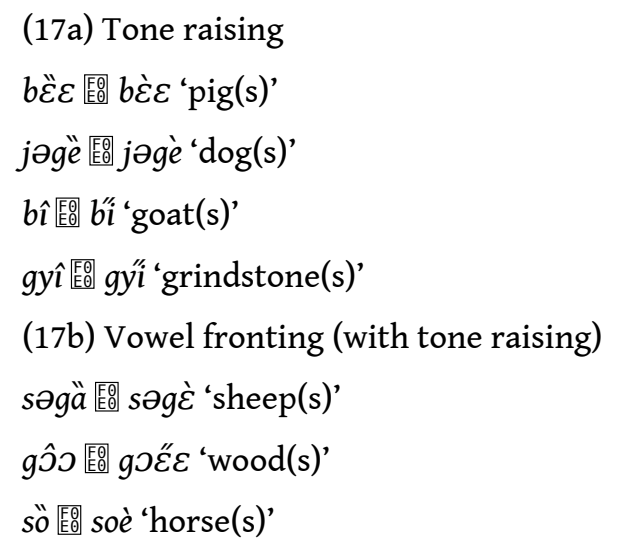

In (17a), we see tone raising one step: $X$ becomes $L$ in the first two examples, while underlyingly H-toned nouns, which surface in the singular as $\mathrm{H}-\mathrm{X}$, become S. Nouns that are already $S$ in the singular, as in the last example in (17b) 'antelope', remain $S$ in the plural. In terms of vocalic changes, (17b) shows us a fronting pattern, where /a/ becomes $[\varepsilon]$ and stems with round vowels form a diphthong with a harmonic front vowel matching the stem for ATR and height. As is typical for Seenku, the diphthonginitial element (formerly the stem vowel in the singular) is nonmoraic, and the original vowel length of the singular stem is transferred to the diphthong-final front vowel. features instantiating the meaning rather than an independent syllable or mora (McPherson 2017a, 2017b). The morpheme consists of two features, a tonal feature [+raised] yielding the tone raising in (17a) and a vocalic feature [+front] yielding the vowel changes in (17b). Diphthongization can be seen as a drive to preserve the feature [+round]. Finally, if the stem vowel is already front, [+front] has no effect (17a), just as the tonal feature [+raised] has no audible effect on lexically $S$ tones.

Returning to plural marking with adjectives, in Seenku, plurality is obligatorily marked on the adjective through a combination of prefixing reduplication and suffixation of 
the plural features; reduplication is partial, copying the initial consonant, which is followed by a fixed high vowel (whose backness depends upon vocalic and consonantal context). ${ }^{9}$ This construction is schematized in (18):

\begin{tabular}{|c|c|c|}
\hline (20b) & gôo & gú-gวย̌ع \\
\hline & wood & RED-dry.PI \\
\hline
\end{tabular}

91 'dry wood (pl.)'

\begin{tabular}{|l|l|l|}
\hline$(20 c)$ & səgå & bú-bəlé \\
\hline & sheep & RED-big.PL \\
\hline
\end{tabular}

\begin{tabular}{|l|l|l|l|}
\hline (20d) & $n ə \ddot{g} \grave{i}$ & $s \hat{\imath}$ & tí-tiě \\
\hline & cow & female & RED-black.PL \\
\hline
\end{tabular}
(19b):

(19a) NOUN RED-ADJ $\mathrm{PL}_{\mathrm{PL}}$

(19b) NOUN $\mathrm{PL}_{\mathrm{PL}}$ RED-ADJ $\mathrm{PL}_{\mathrm{PL}}$

\begin{tabular}{|c|c|c|}
\hline (20a) & gôว & kí-kyəré \\
\hline & wood & RED-fresh.PL \\
\hline
\end{tabular}

'fresh wood (pl.)'

'big sheep (pl.)'

\section{'black cows'}

\section{(18) Schematization of plural marking on adjectives}

NOUN + RED-ADJ-PL ( $C_{1} 1-C_{1}$ V...[+front,+raised] $)$

Most adjectives already end in $\mathrm{S}$ tone and a front vowel, meaning the effects of the plural featural suffix would not be audible. However, in those cases where the adjective ends in a back vowel, we see the effects. The noun may also optionally carry the plural suffix, meaning plural can be marked up to three times in a Noun Adjective construction. The two options are given in (19), where (19a) is more common than

Most commonly, the noun is left in its singular form, as in (20a):

In the case of (20c-d), the adjectival stems are ambiguous as to whether they have taken plural marking or not. Above I have assumed vacuous suffixation of the plural features.

Also commonly accepted, though, are forms with plural marking on both the noun and the adjective: 


\begin{tabular}{|c|c|c|}
\hline (21a) & goع̋ $\varepsilon$ & kí-kyəre̋ \\
\hline & wood.PL & RED-fresh.PL \\
\hline
\end{tabular}

'fresh wood (pl.)'

\begin{tabular}{|l|l|l|}
\hline$(21 \mathrm{~b})$ & $k^{\prime i}$ & sí-səgèe \\
\hline & house.PL & RED-new.PL \\
\hline
\end{tabular}

'new houses'

\begin{tabular}{|l|l|l|}
\hline$(21 c)$ & səg̀̀ & bú-bəlě \\
\hline & sheep.PL & RED-big.PL \\
\hline
\end{tabular}

'big sheep (pl.)'

\begin{tabular}{|l|l|l|l|}
\hline$(21 \mathrm{~d})$ & $n \partial g \grave{i}$ & $s i$ & tí-tiě \\
\hline & cow & female.PL & RED-black.PL \\
\hline
\end{tabular}

'black cows'

Here there are three markers of plurality: the plural suffix on the noun, the plural suffix on the adjective and adjectival reduplication. A comparison with the forms in (20) shows that there is free variation: the same combination of noun and adjective can display different patterns of plural marking. It is possible that the different combinations of plural marking correlate with semantic differences like specificity or definiteness, but I have not found any evidence of these correlations in the data thus far. A larger corpus study would be needed to answer this question.

One unusual case is found in the data in which the adjectival stem does not take its regular plural marking. This is shown in (22), where the noun is unmarked for plural and the adjective is marked with reduplication alone:

\begin{tabular}{|l|l|l|}
\hline$(22)$ & dórô & mú-móën \\
\hline & child & RED-small \\
\hline
\end{tabular}

'small children'

103 Here, dórô 'child' is in the singular and móën is the singular stem for 'small'. Usually the plural for 'small' employs an irregular plural stem məyě, as in the following examples: 


\begin{tabular}{|c|c|c|c|}
\hline (23a) & $\ddot{a}$ & $t s \grave{\sim}$ & 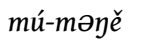 \\
\hline & $3 \mathrm{SG}$ & leg.PL & RED-small.PL \\
\hline
\end{tabular}

'its little legs'

\begin{tabular}{|c|c|c|}
\hline (23b) & gôว & mú-məџе̌ \\
\hline & wood & RED-Small.PL \\
\hline
\end{tabular}
Mande and in certain Southwestern Mande languages, like Loko; data from Seenku shows it to be even more widespread. Solomiac (2014) also notes reduplication of the adjective in Dzùùngoo, suggesting that a reconstruction of this process back to protoMande may not be entirely out of the question.

\section{Adjectival predicates}

112 With a description of adjectival modification in place, we can now turn to adjectival predication, which presents its own unusual characteristics in Seenku. I begin by describing the most common form of adjectival predication in Seenku in $\$ 5.1$ before turning to a couple less common strategies in \$5.2. 


\subsection{SUBJ 'be' REFL ADJ}

This section describes the most basic form of adjectival predication, offered first by consultants (in fact, some consultants have never offered anything different). Adjectival predication involves the copular auxiliary š̃ 'be'. This is the same 'be' verb found as an auxiliary in verbal constructions like the stative construction seen in (9c) above and progressives seen in (37) below, and is distinct from the copula ké used in nominal predication (never used as an auxiliary). To illustrate, we can compare adjectival and nominal predication in (25):

\begin{tabular}{|l|l|l|l|l|}
\hline$(25 \mathrm{a})$ & Mó & sí $^{\prime}$ & $n$ & tiě. \\
\hline & 1SG.EMPH & be & 1SG & black \\
\hline
\end{tabular}

'I am black.'

\begin{tabular}{|l|l|l|l|}
\hline$(25 b)$ & Mó & $k \dot{\varepsilon}$ & $k$ rámbâ. \\
\hline & 1SG.EMPH & COP & student \\
\hline
\end{tabular}

'I am a student.'

116 Neither copular verb agrees with the subject; person/number is indicated entirely by the pronoun (or lack thereof) that precedes the verb (áwó ké 'you (sg.) are N', mí ké 'we

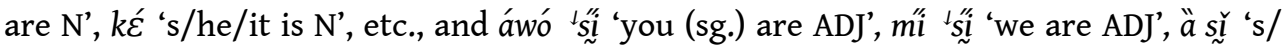
he/it is ADJ', etc.). With adjectival predication, however, we see a surprising addition: another pronoun bound by the subject.

117 The pronoun that appears before adjectives is the reflexive pronoun, which is coindexed with the subject. When the subject is $1 \mathrm{sG}$, as in (26a), the 1SG (non-emphatic) pronoun $n$ is always used. For every other person/number combination, the reflexive pronoun $i$ is used instead:

\begin{tabular}{|c|c|c|c|c|}
\hline (26a) & Mó & ${ }^{\prime}{ }_{S i}^{\prime \prime i} i$ & ń & siž. \\
\hline & 1SG.EMPH & be & $1 S G$ & red \\
\hline
\end{tabular}

118 'I am red.'

\begin{tabular}{|c|c|c|c|c|}
\hline (26b) & Á & ${ }^{\prime}{ }_{S}^{\prime \prime}{ }_{\sim}^{\prime \prime}$ & $i$ & $s_{\sim}{ }_{\sim} \bar{L}_{.}$ \\
\hline & $2 S G$ & be & REFL & red \\
\hline
\end{tabular}

'You are red.' 


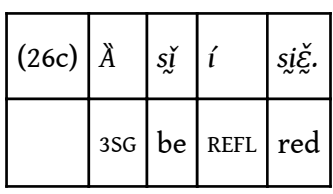

'S/he/it is red.'

\begin{tabular}{|l|l|l|l|l|}
\hline$(26 \mathrm{~d})$ & $M i \hat{i}$ & ${ }^{\prime}{ }_{\sim}^{\prime \prime} \mathrm{i}$ & $i$ & sí-si $\check{\sim}_{\sim}$. \\
\hline & $1 \mathrm{PL}$ & be & REFL & RED-red.PL \\
\hline
\end{tabular}

'We are red.'

The singular pronouns other than the 1sG use the reflexive pronoun $i$, and the example in (26d) show that 1PL does as well; in other words, it is only the combination 1sG that takes a special pronoun.

The reflexive pronoun is also found in coordinated adjectival predicates, as in the following, first with both adjectives overtly coordinated (27a) and the second with the first adjective omitted (27b):

\begin{tabular}{|l|l|l|l|l|l|l|}
\hline (27a) & Jönmä & 's'sí & i & tiě & $i$ & $n \varepsilon$-kă-kă. \\
\hline & cat & be & REFL & black & REFL & cONJ-RED-white \\
\hline
\end{tabular}

124 'The cat is black and white.'

\begin{tabular}{|c|c|c|c|c|}
\hline (27b) & Jögmä & 's'sî & í & 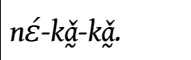 \\
\hline & cat & be & REFL & CONJ-RED-white \\
\hline
\end{tabular}

'The cat is [black] and white.'

Here, the reflexive pronoun occurs before each adjective (if both are used), but interestingly, it occurs before the conjunction, supporting an analysis in which this is a prefix on the adjective rather than a freestanding conjunctive morpheme.

127 Turning to plural marking in non-coordinated adjectival predicates, by far the most common form involves both suffixation and reduplication of the adjective, as we saw in modification above:

\begin{tabular}{|l|l|l|l|l|l|}
\hline$(28 \mathrm{a})$ & $\grave{I}$ & bruì & š̃ & $i$ & bú-bəlě. \\
\hline & $3 \mathrm{PL}$ & nose.PL & be & REFL & RED-big.PL \\
\hline
\end{tabular}

'Their noses are big.' 


\begin{tabular}{|c|c|c|c|c|}
\hline$(28 b)$ & Jönme̋ & ${ }^{\prime}$ s's $_{\sim}^{\prime \prime}$ & $i$ & 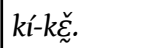 \\
\hline & cat.PL & be & REFL & RED-white.PL \\
\hline
\end{tabular}

'The cats are white.'

\begin{tabular}{|l|l|l|l|l|l|}
\hline$(28 \mathrm{c})$ & Bî & gyünìi & š̌ & $i$ & tí-tie. \\
\hline & goat.PL & eye.PL & be & REFL & RED-black.PL \\
\hline
\end{tabular}

'The goat's eyes are black.'

Though one consultant rejected any attempts to use an unreduplicated form of the adjective, another consultant readily offered the following forms, corresponding to $(26 \mathrm{~d})$ and $(28 \mathrm{c})$, respectively:

\begin{tabular}{|c|c|c|c|c|}
\hline$(29 a)$ & Mí & ${ }^{{ }^{\prime}} \mathbf{S i}_{i}^{\prime i}$ & $i$ & $s i{ }_{\tilde{\alpha}}$. \\
\hline & $1 \mathrm{PL}$ & be & REFL & red \\
\hline
\end{tabular}

'We are red.'

\begin{tabular}{|l|l|l|l|l|l|}
\hline$(29 b)$ & Bî & gyünìi & š & $i$ & tie. \\
\hline & goat.PL & eye.PL & be & REFL & black.PL \\
\hline
\end{tabular}

'The goat's eyes are black.'

In other words, while reduplication is the preferred method of plural marking for adjectives as both modifiers and predicates, this preference is weaker in predicate adjectives.

When coordinated adjectives are marked as plural, we see more variation. The first adjective, if mentioned, is obligatorily reduplicated using the plural CV reduplicant. The second adjective undergoes the full reduplication pattern characteristic of coordination and is optionally suffixed for plural. If the plural suffix is present, its effects appear in both the base and the reduplicant:

\begin{tabular}{|c|c|c|c|c|c|c|c|}
\hline (30a) & Jöyme̋ & $b \varepsilon$ & ${ }^{\prime}{ }_{S \sim}^{\prime \prime} i$ & $i$ & tí-tiě & $i$ & $n \varepsilon-k \underset{\sim}{a}-k a \grave{a}$. \\
\hline & cat.PL & DEM.PL & be & REFL & RED-black & REFL & CONJ-RED-white \\
\hline
\end{tabular}

'Those cats are black and white.' 


\begin{tabular}{|c|c|c|c|c|c|c|c|}
\hline (30b) & Jönmé & $b \varepsilon$ & ${ }^{\prime}{ }_{\sim}^{\prime \prime i}$ & $i$ & tí-tiě & $i$ & 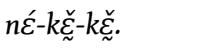 \\
\hline & cat.PL & DEM.PL & be & REFL & RED-black & REFL & CONJ-RED-white.PL \\
\hline
\end{tabular}

'Those cats are black and white.'

My data do not contain any cases of coordinated plural predicates in which the first adjective is implied rather than overt. More research is required to uncover whether other plausible but unattested patterns are possible, such as plural reduplication of the second adjective rather than coordinated reduplication.

\subsection{Other predicate constructions}

Though the constructions in $\$ 5.1$ are clearly the default in Seenku, at least one other predicate structure is attested. In all such cases in my data, the subject is modified by a demonstrative ('this cat', 'this tree', etc.). The adjective immediately follows the subject with no copula and no reflexive prefix, but with an $\mathrm{X}$ or $\mathrm{H}-\mathrm{X}$ tone pattern rather than its usual L-S:

\begin{tabular}{|l|l|l|l|l|}
\hline (31a) & (æ̈) & gว̂J-kü & bé & bəlë. \\
\hline & 3SG & wood-plant & DEM & big.PRED \\
\hline
\end{tabular}

'This tree is big.'

\begin{tabular}{|l|l|l|l|l|}
\hline$(31 b)$ & $(\grave{A})$ & jöymäa & bé & tiè. \\
\hline & 3SG & cat & DEM & black.PRED \\
\hline
\end{tabular}

\section{'This cat is black.'}

The adjective 'big' in the predicate position is X, while 'black' is $\mathrm{H}-\mathrm{X}$. This suggests an underlying $\mathrm{X}$ vs. $\mathrm{H}$ tone distinction that is neutralized in the regular adjectival context to L-S. Interestingly, for 'black', the /i/ portion of the diphthong receives emphasis rather than being a glide, as it typically is in other cases. These constructions are reminiscent of present perfectives in Seenku, where intransitive verbs display one of three lexical melodies, X, H, or H-X. Given the distinctions laid out in $\$ 3$, however, it is surprising that members of the core set of adjectives have any overlap in morphosyntactic function with verbs. I have never seen this construction in texts or narratives and thus it remains an open question as to its frequency and any semantic differences from the regular predicate construction in $\$ 5.1$; my consultant claims they are interchangeable.

3 Finally, one other form has been identified that may or may not be different from the default in \$5.1. Consider the following: 


\begin{tabular}{|l|l|l|l|l|l|}
\hline$(32)$ & Mó & ${ }^{\prime \prime s} \hat{i}$ & $n$ & bəlě & wé. \\
\hline & 1SG.EMPH & be & 1SG.REFL & big & ?? \\
\hline
\end{tabular}

'I am not fat!'

\section{'I am not fat!'} (34b):

The identity of $w \varepsilon$ here is not entirely clear. On the one hand, we might translate this as the postposition 'with', which would put the construction in line with what is seen in Guro and Wan (see 38-39 below). But on the other hand, the meaning of this construction appears to be emphatic, translated by my consultant using the Dioula emphatic $d \varepsilon$, suggesting that wé might be instead an emphatic particle. Corroborating evidence for this hypothesis comes from the negative, which can be either:

\begin{tabular}{|l|l|l|l|l|l|l|}
\hline (33a) & Mó & já & $n$ & bəlě & wé & yé. \\
\hline & 1SG.EMPH & be & 1SG.REFL & big & $? ?$ & NEG \\
\hline
\end{tabular}

\begin{tabular}{|c|c|c|c|c|c|c|}
\hline (33b) & Mó & já & $n$ & bəlě & $\eta \varepsilon$ & wé. \\
\hline & 1SG.EMPH & be & 1SG.REFL & big & NEG & ?? \\
\hline
\end{tabular}

The negative particle $\eta \varepsilon ́$ is clause-final in Seenku and has never before been seen intervening between a postposition and its noun. If wé is instead an emphatic discourse particle, it may have more flexibility in word order. Assuming this is the case, then, the constructions in (32) and (33) are in fact no different from those in \$5.1.

\section{Discussion}

9 This paper has described adjectival modification and predication in Seenku. The patterns of modification are not substantially different from what we see elsewhere in Mande, with plural reduplication seen elsewhere in the Samogo group as well as in Southwestern and South Mande languages. The default predication strategy, on the other hand, is a bit more unusual.

In many Mande languages, such as Vai and related Central Mande languages (Tröbs 2014), qualificative predication will follow either a nominal or a verbal strategy. In Vai, for instance, adjectives can follow nominal, locational, or verbal predication strategies. The nominal strategy is given in (34a), with a true nominal predicate contrasted in

\begin{tabular}{|l|l|l|l|}
\hline$(34 a)$ & À & lólì & mù. \\
\hline
\end{tabular}




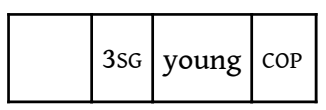

'He is young.'

\begin{tabular}{|c|c|c|c|c|c|}
\hline (34b) & $y$ & ggój & kòlà & léć-mò & mù. \\
\hline & $1 S G$ & older.brother & cloth & weave-person & COP \\
\hline
\end{tabular}

'My older brother is a weaver.'

In both cases, the noun or the adjective precedes the copular mù. As (25) showed above, the copular construction used nominally in Seenku is not the same as adjectival predication.

154 Vai adjectival predicates can also follow a locational strategy, shown in (35a) with a contrasting locational predicate in (35b):

\begin{tabular}{|l|l|l|l|}
\hline (35a) & Kàí̌ & $6 \grave{\varepsilon}$ & kúndú. \\
\hline & man.DEF & LOC.COP & short \\
\hline
\end{tabular}

'The man is short.'

\begin{tabular}{|l|l|l|l|l|}
\hline (35b) & Kàlàă & $6 \grave{\varepsilon}$ & sěy ̌̌ & mà. \\
\hline & snake & Loc.coP & rock.DEF & surface \\
\hline
\end{tabular}

156 'The snake is on the rock.'

157 This strategy is closer to what we see in Seenku, in that the same copular verb is used in both locational and adjectival predicates. However, the two constructions in Seenku still differ in the unusual appearance of a reflexive pronoun for adjectives, not present locationally:

\begin{tabular}{|l|l|l|l|l|}
\hline$(36 \mathrm{a})$ & $\hat{A}$ & ${ }^{\text {ISSí }}$ & $i$ & tiě. \\
\hline & $2 \mathrm{SG}$ & be & LOG & black \\
\hline
\end{tabular}

'You are black.'

\begin{tabular}{|l|l|l|l|l|}
\hline$(36 \mathrm{~b})$ & Mó & $\iota^{\prime}$ 'î & səgîi & $n \tilde{\varepsilon}$. \\
\hline & 1SG.EMPH & be & market & in \\
\hline
\end{tabular}


'I am at the market.'

The Seenku adjectival predicate form also differs from any verbal forms; the progressive exactly mirrors (36b), including the use of a postposition, while the stative verbs precede the 'be' auxiliary:

\begin{tabular}{|l|l|l|l|l|}
\hline (37a) & Mó & ${ }^{'}$ 'ši & səmâ & $n \tilde{\varepsilon}$. \\
\hline & 1SG.EMPH & be & dance & in \\
\hline
\end{tabular}

'I am dancing.'

\begin{tabular}{|l|l|l|l|l|}
\hline$(37 b)$ & Mó & təği & ${ }^{\text {'šìi. }}$ & \\
\hline & 1SG.EMPH & stand.PTCP & be & \\
\hline
\end{tabular}

'I am standing' (repeated from 8c).

Thus, in Seenku, adjectival predication is distinct from both nominal and verbal predication, in direct contradiction to Stassen's (1997) Adjective Principle, that no language has a special way of encoding adjectival predicates.

Looking within Samogo, Dzùùngoo likewise offers no parallels, with adjectival predication typically encoded through a bare SUBJ ADJ construction (Solomiac 2014). Duungoma (Tröbs 2008) is also dissimilar, either employing a SUBJ VERB construction with property verbs or using nominal predication, considering the majority of adjectives in the language are productively derived from nouns. Elsewhere in Northwest Mande, Soninke mirrors Seenku's use of L-S tone on adjectives (in Soninke, a L-H replacive melody is applied to predicative adjectives), but the predicate construction involves a post-adjectival copula and no reflexive pronoun (Creissels 2015). Bobo likewise shows a predicate structure in which the adjective resembles an intransitive verb (perhaps not dissimilar from the alternative Seenku construction in \$5.2); no copula or reflexive pronoun are present (Kate Sherwood, p.c.).

Can we find any parallels in Mande for the Seenku reflexive construction? In fact, a similar construction is sparsely attested in a few South Mande languages. For instance, in Guro (Kuznetsova and Kuznetsova 2017), there are a couple of constructions with socalled qualitatives (displaying features of both adjectives and adverbs) that employ a reflexive pronoun. For instance:

\begin{tabular}{|l|l|l|l|l|l|l|l|}
\hline (38a) & $F \bar{\varepsilon}_{i}$ & $(\mathbf{l} \hat{u})$ & $\grave{a}$ & é/wó & $\bar{t} i$ & $(\hat{l} \hat{u})$ & $y \bar{a}$. \\
\hline & thing & PL & COP & 3SG.REFL/3PL.RFL & black & PL & with \\
\hline
\end{tabular}

'Thing(s) is/are black.'

\begin{tabular}{|l|l|l|l|l|l|l|l|}
\hline$(38 \mathrm{~b})$ & $F \bar{\varepsilon}_{i}$ & $(l \hat{u})$ & $\grave{a}$ & $e^{*}{ }^{*} w_{i}$ & $\bar{t} \hat{i}$ & $(l \hat{k})$ & $y \bar{a}$. \\
\hline
\end{tabular}




\begin{tabular}{|l|l|l|l|l|l|l|l|}
\hline & thing & PL & COP & PREP/3PL.RFL & black & PL & with \\
\hline
\end{tabular}

'Thing(s) is/are dark.'

In Guro, the preposition é is homophonous with the $35 \mathrm{SG}$ reflexive pronoun, making singular sentences ambiguous in their structure. With the plural, however, the two are distinguished, as shown in (38a). The sentence in (38b) shows that the use of the pronoun is correlated with semantics (subjective evaluation of the speaker, etc.); for the reading 'dark', only the preposition can be used. Of interest is the fact that the pronoun (as opposed to the preposition) in Guro obligatorily co-occurs with the postposition 'with' after the adjective, suggesting a literal translation like 'It is with its blackness'.

9 The same construction is found in Wan (Nikitina 2017), where it is the normal way of predicating adjectives (39a). When the subject is first or second person rather than third, a normal inalienable possessive pronoun is used in place of the reflexive (39b):

\begin{tabular}{|l|l|l|l|l|}
\hline (39a) & Yàa & $\bar{e}$ & kpālé & $y \bar{a}$. \\
\hline & 3SG.COP & REFL & difficulty & with \\
\hline
\end{tabular}

70 'It is difficult.' (lit. 'It is with its own difficulty')

\begin{tabular}{|l|l|l|l|l|}
\hline$(39 b)$ & Lāá & lā & kpālé & $y \bar{a}$. \\
\hline & 2SG.COP & 2SG & difficulty & with \\
\hline
\end{tabular}

'You (sg.) are difficult' (lit. 'You are with your own difficulty').

The Guro and Wan constructions are unlike Seenku, where the adjective is never followed by a postposition (unless the form analyzed as an emphatic in 32 is instead analyzed as 'with'). The 'with' construction is nonetheless reminiscent of a predicate strategy for deverbal qualification in Seenku, where rather than placing the participle before the 'be' verb š̃ , it follows it, preceded by the reflexive pronoun and followed by the postposition 'with', as in:

\begin{tabular}{|c|c|c|c|}
\hline (40a) & Kyəbह̋ $\varepsilon$ & sənع̋ & ${ }^{\prime}$ Sili. \\
\hline & shoe.PL & wet.PTCP & be \\
\hline
\end{tabular}

'The shoes are wet.'

\begin{tabular}{|c|c|c|c|c|c|}
\hline (40b) & Kуəьह̋ & ${ }^{\perp}{ }_{\sim}^{\prime \prime i}$ & $i$ & sənع̋ & wê. \\
\hline & shoe.PL & be & REFL & wet & with \\
\hline
\end{tabular}


'The shoes are wet.'

Note the lack of plural reduplication on participial predicates. My consultant indicates no difference in meaning between the two forms in (40), though perhaps a corpus of natural speech may reveal subtle differences in usage.

Finally, Yaure (Elizaveta Kushnir, p.c.) offers the closest parallel to Seenku adjectival predication. While the reflexive pronoun is found in many verbal resultative constructions (41a), it is also attested with a small set of seven adjectives, including the adjective 'new' (41b):

\begin{tabular}{|l|l|l|l|l|}
\hline (41a) & $\grave{E}$ & $\grave{a}$ & $\grave{e}$ & yìlà-dì. \\
\hline & 3SG.SBJ & COP & 3SG.REFL & sleep-PTCP \\
\hline
\end{tabular}

\section{'He is asleep.'}

\begin{tabular}{|l|l|l|l|l|}
\hline$(41 b)$ & $P \ddot{z}$ & $\grave{a}$ & $e ́$ & tëlě. \\
\hline & pot & COP & 3SG.REFL & new \\
\hline
\end{tabular}

'The pot is new.'

179 As in Seenku, no postposition follows the adjective. The construction in (41b) is thus an exact parallel of what we see in Seenku, though its usage in Yaure is reportedly much more constrained.

The examples we have seen above show that Seenku is not the only Mande language to employ a reflexive pronoun in adjectival predicates, but it is unusual in having this be the sole (or at least the default) predicate construction with the closed class of adjectives. I will end this paper with a speculation of how such a construction could have arisen. As I noted in $\$ 3$, adjectives cannot stand alone in a noun phrase; the adjective must always be supported by a dummy noun (like English 'one' in 'a black one'). In Seenku, this slot is filled by the 3sG pronoun ä. If we consider that the verb 'be' as a copula requires an NP to follow it, then the $\mathrm{N}$ slot must be filled with a pronoun to prop up the adjective. In other words, 'be' [ Adjective $]_{\mathrm{NP}}$ is ungrammatical for the same reason that [ Adjective $]_{\mathrm{NP}}$ is ungrammatical elsewhere in the language. ${ }^{10}$ Since the subject of the adjectival predicate is co-referential with the adjective, the pronoun in the adjective's NP must be coindexed and thus surfaces as the reflexive. This is a similar proposal to Nikitina (2017), who argues that adjectives are nominal syntactic heads that require an argument. It remains to be seen whether this diachronic pathway is the same for all languages that use the reflexive pronoun in adjectival predication.

In summary, this paper has briefly described the morphosyntax of the class of true adjectives in Seenku, which display interesting patterns of plural marking and an unusual reflexive construction when used predicatively. An interesting result of this study is to highlight at least two areas in which Seenku or the Samogo languages align more with South Mande than with their closer genetic relatives: reduplicative plural marking on adjectives (Samogo) and the presence of the reflexive pronoun in adjectival 
predication (Seenku), not to mention the complexity of Seenku's tone and its sesquisyllabic restructuring. Future work should focus on the diachronic paths that led to these convergences.

\section{Abbreviations}

\begin{tabular}{|l|l|}
\hline COP copula & PL plural \\
DEF definite & PTCP participle \\
DERIV derivation & PST past \\
EMPH emphatic & REAL realis \\
GEN generic & RED reduplicant \\
IRREAL irrealis & REFL reflexive \\
LOC locational & SG singular \\
PFV perfective & \\
\hline
\end{tabular}

\section{BIBLIOGRAPHY}

Brunelle, Marc and Pittayawat Pittayaporn. 2012. Phonologically-constrained change: the role of the foot in monosyllabization and rhythmic shifts in Mainland Southeast Asia. Diachronica 29:4, pp. 411-433. DOI: 10.1075/dia.29.4

Butler, Becky A. 2014. Deconstructing the Southeast Asian Sesquisyllable: A Gestural Account. Doctoral dissertation, Cornell University.

Creissels, Denis. 2005. La notion d'adjectif dans une perspective typologique. In Jacques François (ed.), L'adjectif en français et à travers les langues. Caen: Presse Universitaire Caen, pp. 73-88.

Creissels, Denis. 2015. The inflectional role of tone in Soninke (West Mande). Paper presented at the $45^{\text {th }}$ Colloquium on African Languages and Linguistics, Leiden.

Dixon, Robert M.W. 1982. Where have all the adjectives gone? In: Dixon (ed.). Where have all the adjectives gone? and other essays in semantics and syntax. Berlin: Mouton, pp. 1-62.

Green, Christopher. 2010. Prosodic phonology in Bamana (Bambara): Syllable complexity, metrical structure, and tone. Doctoral dissertation, Indiana University.

Houis, Maurice. 1977. Plan de description systématique des langues africaines. Afrique et Langage 7, pp. 1-26.

Kuznetsova, Natalia V. and Olga V. Kuznetsova. 2017. Guro jazyk. In: Valentin F. Vydrin, Yulia V. Mazurova, Andrej A. Kibrik \& Elena B. Markus (eds.). Jazyki mira: Jazyki mande. [Languages of the World: Mande Languages.] St. Petersburg: Nestor-Historia, pp. 765-877. 
Matisoff, James A. 1990. Bulging monosyllables: Areal tendencies in Southeast Asian diachrony. Proceedings of the Sixteenth Annual Meeting of the Berkeley Linguistics Society, pp. 543-559.

McPherson, Laura. 2017. Tone features revisited: evidence from Seenku. In Doris Payne, Sara Pacchiarotti, and Mokaya Bosire (eds.) Diversity in African Languages: Selected papers from the $46^{\text {th }}$ Annual Conference on African Linguistics. Berlin: Language Science Press, pp. 5-22.

McPherson, Laura. In press. Multiple feature affixation in Seenku plural formation. Morphology. Nikitina, Tatiana. 2017. Wan jazyk. [The Wan language.] In: Valentin F. Vydrin, Yulia V. Mazurova, Andrej A. Kibrik \& Elena B. Markus (eds.). Jazyki mira: Jazyki mande. [Languages of the World: Mande Languages.] St. Petersburg: Nestor-Historia, pp. 1032-1050.

Prost, André. 1971. Eléments de Sembla: Phonologie - Grammaire - Lexique. Lyon : Afrique et Langage. Pulleyblank, Douglas. 1986. Tone in Lexical Phonology. Studies in Natural Language and Linguistic Theory. Dordrecht, Netherlands ; Boston ; Lancaster, Great Britain : D. Reidel Segerer, Guillaume. 2008. Closed adjective classes and primary adjectives in African languages. $<$ halshs-00255943>

Solomiac, Paul. 2014. Phonologie et morphosyntaxe du Dzùùngoo de Samoghori. Köln: Rüdiger Köppe Verlag.

Stassen, Leon. 1997. Intransitive Predication. Oxford: Clarendon Press.

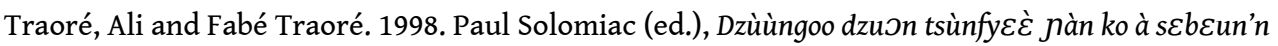
kur'la. Lexique orthographique dzùùngoo-français. Société Internationale de Linguistique.

Tröbs, Holger. 2008. Duun. In: Holger Tröbs, Eva Rothmaler, and Kerstin Winkelmann (eds.). La qualification dans les langues africaines. Köln: Rüdiger Köppe Verlag, pp. 71-86.

Tröbs, Holger. 2014. Some notes on the encoding of property concepts in Vai from a typological and comparative Central Mande perspective. Mandenkan 52, pp. 111-130.

Vydrine, Valentin. 2004. La réduplication des adjectifs dans les langues mandé. Mandenkan 39, pp. 61-67.

Vydrine, Valentin. 2007. Les adjectifs en dan-gwèèta. Mandenkan 43, pp. 77-104.

Vydrine, Valentin. 2009. On the problem of the Proto-Mande homeland. Journal of Language Relationship 1, pp. 107-142.

Vydrine, Valentin. 2016. Toward a Proto-Mande reconstruction and an etymological dictionary. Faits de langues 47, pp. 109-123. <http://fdl.univ-lemans.fr/fr/index.html>. <halshs-01375776> Welmers, William E. 1973. African language structures. Los Angeles: University of California Press. Zheltov, Alexander. 2008. Some elements of Gban grammar and linguistic typology. In: Vydrin (ed.), Mande languages and linguistics, $2^{\text {nd }}$ international conference, St. Petersburg (Russia), September 15-17, 2008. Abstracts and papers. St. Petersburg, pp. 126-130.

\section{NOTES}

1. The tonal transcription system used in this paper requires brief comment. Tone is a property of syllable or syllable cluster (meaning the combination of a minor/half syllable and the main syllable of a sesquisyllabic word). As such, it is marked only once on the main vowel. Sesquisyllables are pronounced on the same tone as the first tone of the main syllable, so a word 
like səmâ 'dance' would carry $\mathrm{H}$ on both the minor syllable and the beginning of the main syllable. For consistency in marking tonal melodies, the same diacritics are used for contour tones on long and short vowels. On diphthongs, tone is marked on the second vocalic element, since the first is typically non-moraic and acts more like a glide.

2. There is some variation between consultants; younger consultants typically do not reconstruct a vowel, while older consultants do. It is likely that this is a change in process, but more systematic checking with consultants of varying ages would be revealing.

3. The feature [ATR] here is used to distinguish between the mid vowels. Acoustically, the difference between $[\mathrm{e}] /[\varepsilon]$ and $[\mathrm{o}] /[\mathrm{o}]$ sounds like more than simply height differences, suggesting the involvement of tongue root, though instrumental measurements such as ultrasound have not been carried out.

4. It is unclear whether this reduction in the diphthong-initial vowel is related to the general initial vowel reduction seen across the language.

5. The environment $\mathrm{VrV}$, especially $\mathrm{kVrV}$, is the most disyllabic-sounding sequence in the language. I have transcribed these words as disyllabic, outside of the normal sesquisyllabic pattern, to reflect their phonetic realization but leave theoretical claims about their underlying structure for future work.

6. I have seen the conjunction tsə̋nć used for nouns in a text, which may have a reflex of this coordinating $n \varepsilon^{-}$- prefix, but this seems like a more archaic form.

7. This form can also precede the copular verb, like a deverbal modifier, but in this position it takes on the meaning 'old' or 'aged' rather than 'tall'. I treat this as an irregular, idiomatic construction.

8. The term sü refers to both duikers (Sylvicapra grimmia) as well as oribis (Ourebia ourebi).

9. There is also some interspeaker variation in this regard, with some speakers reduplicating the vowel of the stem rather than using a fixed high vowel.

10. Many thanks to Maksim Fedotov for suggesting this parallel.

\section{ABSTRACTS}

Seenku (Samogo, Northwestern Mande) contains a small class of adjectives, which differ morphosyntactically from deverbal modifiers (qualificational verbs) and nouns. This paper describes the morphosyntax of these adjectives as both modifiers and predicates. Modifiers follow the noun, with no tonal interactions. Plural marking is obligatory on the adjective through reduplication and suffixation, the latter of which is optionally doubled on the noun. As predicates, adjectives follow the copular verb but are always preceded by a reflexive pronoun coindexed with the subject. I compare these constructions to other Mande languages and suggest a diachronic path for the unusual predicate construction.

Le seenku (Samogo, Mandé Nord-ouest) contient un inventaire limité d'adjectifs, qui diffèrent en morphosyntaxe des modificateurs verbaux (verbes qualificatifs) et des noms. Cet article décrit la morphosyntaxe de ces adjectifs en tant que déterminants et prédicats. Les déterminants suivent le nom sans interaction tonale. Le pluriel est obligatoirement marqué sur l'adjectif avec la réduplication et la suffixation, celui-ci étant facultativement marqué sur le nom aussi. En tant que prédicats, les adjectifs suivent le verbe copulaire mais ils sont toujours précédés par un pronom réfléchi co-indexé avec le sujet. Je compare ces constructions avec celles dans les autres 
langues mandé et je suggère un chemin diachronique pour cette construction prédicative atypique.

СЕЕНКУ (ГРУППА САМОГО, СЕВЕРОЗАПАДНЫЕ МАНДЕ) ИМЕЕТ ОГРАНИЧЕННОЕ КОЛИЧЕСТВО ПРИЛАГАТЕЛЬНЫХ, КОТОРЫЕ ОТЛИЧАЮТСЯ МОРФОСИНТАКСИЧЕСКИ ОТ ГЛАГОЛОВМОДИФИКАТОРОВ (КВАЛИТАТИВНЫХ ГЛАГОЛОВ) И ОТ СУЩЕСТВИТЕЛЬНЫХ. В СТАТЬЕ ОПИСАН

МОРФОСИНТАКСИС ЭТИХ ПРИЛАГАТЕЛЬНЫХ В ФУНКЦИИ ОПРЕДЕЛЕНИЙ И ПРЕДИКАТОВ. В ФУНКЦИИ ОПРЕДЕЛЕНИЯ, ПРИЛАГАТЕЛЬНОЕ СЛЕДУЕТ ЗА СУЩЕСТВИТЕЛЬНЫМ, НЕ ВСТУПАЯ С НИМ В ТОНАЛЬНОЕ ВЗАИМОДЕЙСТВИЕ. МНОЖЕСТВЕННОЕ ЧИСЛО ОБЯЗАТЕЛЬНО МАРКИРУЕТСЯ НА ПРИЛАГАТЕЛЬНОМ РЕДУПЛИКАЦИЕЙ ИЛИ СУФФИКСАЦИЕЙ, ПРИЧЁМ СУФФИКС МОЖЕТ ФАКУЛЬТАТИВНО ПРИСОЕДИНЯТЬСЯ ТАКЖЕ К СУЩЕСТВИТЕЛЬНОМУ. В ФУНКЦИИ ПРЕДИКАТА ПИЛАГАТЕЛЬНОЕ СЛЕДУЕТ ЗА ГЛАГОЛОМ-КОПУЛОЙ, ПОМИМО ЭТОГО, ЕМУ ОБЯЗАТЕЛЬНО ПРЕДШЕСТВУЕТ ТАКЖЕ РЕФЛЕКСИВНОЕ МЕСТОИМЕНИЕ, КОРЕФЕРЕНТНОЕ ПОДЛЕЖАЩЕМУ. Я СРАВНИВАЮ ЭТИ КОНСТРУКЦИИ С ТАКОВЫМИ В ДРУГИХ ЯЗЫКАХ МАНДЕ И ПРЕДЛАГАЮ ДИАХРОНИЧЕСКИЙ МАРШРУТ ДЛЯ ЭТОЙ НЕСТАНДАРТНОЙ ПРЕДИКАТИВНОЙ кОНСТРУКцИИ.

\section{INDEX}

Mots-clés: adjectif, pluriel, morphosyntaxe, prédicat, redoublement, réfléchi, modificateurs, quantification, seenku

Keywords: adjective, plural, morphosyntax, predicate, reduplication, reflexive, modifiers, qualification, Seenku motsclesru ПРИЛАГАТЕЛЬНОЕ, МНОЖЕСТВЕННОЕ ЧИСЛО, МОРФОСИНТАКСИС, ПРЕДИКАТ, РЕДУПЛИКАЦИЯ, РЕФЛЕКСИВ, ОПРЕДЕЛЕНИЕ, КВАНТИФИКАЦИЯ, СЕЕНКУ

\section{AUTHOR}

\section{LAURA MCPHERSON}

Dartmouth College, USA

laura.emcpherson@gmail.com 